\title{
KATARZYNA ZIELIŃSKA
}

\section{Concepts of religion in debates on secularisation}

$\mathrm{D}$ efining the concept of religion is a recurring theme in the sociology of religion. Yet the constant attempts to determine the subject of the study do not necessarily indicate the immaturity of the discipline. The ongoing discussions are rather part of a broader problem, as the acceptance or rejection of certain understandings of the core concepts determines the scope of the discipline's field. More importantly, it also permits other concepts to be understood, along with the social reality beyond them. Since the social reality is changing under the influence of various dynamics taking place in the contemporary globalised world, so should the conceptual apparatus aiming at describing those dynamics. This paper aims to grasp this changing nature of the central concept - that of religion. This is done through analysis of the debate on secularisation theories.

\section{Sociology of what? Struggling to define the subject}

Defining religion is a very difficult task, not only in the field of the sociology of religion but also in other disciplines dealing with this phenomenon (e.g. the philosophy of religion, religious studies). In the field of the sociology of religion difficulties with defining the subject of our studies can already be traced in the writings of the 'founding fathers' of sociology. Max Weber, at the beginning of his work on religion, claimed that the definition of religion can only be worked out at the end of a study, rather than at its outset (Weber 1978: 399). Émile Durkheim pointed to the limitations stemming from the cultural embeddedness of defining concepts, which are meant to be universal (Durkheim 2001: 25-6). Karl Marx, on the other hand, perceived religion as a product of alienation which would disappear with the elimination of the conditions causing it (Marx and Engels 2008: 42).

Attempts to define the subject matter of the sociology of religion were further complicated by the 'religious heritage' of the discipline itself. Initially it was developed by religious institutions interested in understanding the changing nature of the religious practices of European and American populations after World War II. The first sociological research on the condition of religion was mostly done under the auspices of both the Catholic and Protestant Churches, which limited the scope of interest of the researchers (Schreuder 1966, Dobbelaere 1968). Hence, in this research religion was frequently understood in terms based on the particularity of Christianity and its specific institutional forms. Such a 'religious heritage' of the discipline became a subject of concern among the sociologists in the 1960 and the early 1970 s. Discussions focused not only on the need to secularise the discipline (Dobbelaere 2000: 435), but also pointed to the limitations of the concepts used in it, i.e. religion, religiosity, and secularisation (Robertson 1970, Luckmann 1963).

In terms of the topic of this article, the discussions on the concept of religion are of particular interest. Initially, in the 1960s, the main theme was the problem of what today might be called the cultural embeddedness of the concept. Scholars pointed to the exclusive character of the definitions of religion based on the Christian peculiarities and their ethnocentricity (Cohn and Klausner 1962: 25; Luckmann 1963: 148). These early debates contributed to the attempts to redefine the concept and reach beyond the limitations imposed by Christian heritage. They called for more inclusive definitions of religion. In this context Thomas Luckmann coined his definition of religion in which it is understood as the transcendence of biological nature by the human organism' (Luckmann 1967: 48). As a consequence, '[f]rom the narrowly institutional, the notion of religion becomes quite simply part of being human; it is that which transcends biological nature' (Davie 1998: 148). Similarly, James E. Dittes (1969) spoke of secular religion as a phenomenon characteristic 
of modern societies, where religious elements may more likely be found in various spheres such as the family and politics than in the religious sphere. Will Herberg's (1962) proposal of operationalised religion and Robert Bellah's (1967) notion of civil religion can also be interpreted in this spirit.

Deliberations on the subject of study continued in the 1970s. However, then they concentrated largely on the differences between substantial and functional definitions of religion. They focused respectively on defining religion in terms of the contents of the phenomena pertaining to it, or in terms of its place and role in the social and/or psychological systems (Berger 1974: 126), and on the applicability of those definitions (Berger 1974, Luckmann 1977). Both types of definitions have their supporters and critics. Substantive definitions are often accused of being culturally specific (King 1999 in Bruce 2011: 112; Dobbelaere 2011: 193). On the other hand functional definitions are often perceived as too inclusive (Bruce 2011: 110; Dobbelaere 2011: 192), difficult to operationalize (Weigert 1974) and ideological (Berger 1974: 127). Reaching beyond the question of the usefulness and validity of both types of definitions, some scholars interpret these discussions as attempts to de-Westernise the sociology of religion and as enabling the inclusion of non-Christian religions in the field of the sociology of religion (Voyé 2004).

Currently, the problem of defining the subject of the discipline seems still to persist in the sociology of religion (e.g. International Sociology Review, March 2011). Yet constant attempts to determine the parameters of the subject do not necessarily indicate its immaturity. The ongoing discussions are rather part of a broader problem, as acceptance or rejection of certain understandings of the core concepts determines the scope of the discipline's field. More importantly, it also permits other concepts to be understood, along with the social reality beyond them. Since the social reality is changing under the influence of various dynamics taking place in the contemporary globalised world, so should the conceptual apparatus aiming at describing those dynamics. However, we may ask the question: to what extent is this true?

This paper aims to grasp the changing notion of the central concept - that of religion. This is done through an analysis of the debates about secularisation theories which indicate well the widening focus of the sociology of religion as it aims to embrace changing social realities.

\section{Debates on secularisation - what are they about?}

The question of secularisation as a theoretical model or a social reality seems to be a recurring theme in the sociology of religion. As early as the 1960s, when the initial theories were constructed, scholars in the field argued that the term was ideologically loaded (Martin 1965: 182). Not only was the usage of the concept criticised, but the existence of the secularisation process itself was put in doubt (Greeley 1972: 2-3). Despite all reservations, theories about secularisation seemed to offer the best explanation for the religious transformations taking place in modern (Western) societies. With time those approaches were accepted by scholars in the field and widely used in interpretations of the observed changes regarding religion which were taking place in modern society.

Steadily, more and more empirical data showing the persistence, or resurgence, rather than weakening, of various religions started to challenge the assumptions behind secularisation theories. The crucial moment from the point of view of an intensification of the debate was the emergence of the first articles presenting the arguments which outlined a theory of religious economy, as described by Rodney Stark and William Sims Bainbridge (1980). The new theory, in the opinion of its authors, would be better equipped to cope with the anomalous observations emanating from the USA, which were problematic from the point of view of secularisation theories. It was also supposed to offer better explanations for changes taking place in other parts of the world.

Observations coming from around the world became a further challenge to the assumptions of the secularisation paradigm. Particularly the Islamic Revolution in Iran, the growth of the New Christian Right and the emergence of religious fundamentalisms and radicalisms contradicted assumptions about the separation of religion from the public sphere and its privatisation (Casanova 1994, Shupe and Hadden 1998). The third element contributing to the discussion was a growing number of new religious movements, as well as new forms of religion; phenomena particularly visible in Western Europe (Knoblauch 2003). The old model was not able to deal successfully with these observations, which in Kuhnian language could be called anomalies. Hence, it intensified a debate on the limitations of the old paradigm and the search for new approaches.

The discussion in question embraces the most recent theoretical and empirical developments in the sociology of religion, so the analysis of the arguments of the dispute will allow hidden assumptions and 
limitations to the conceptual apparatus of the discipline to be revealed. In the following I will attempt to present the focus of these discussions and, more importantly, indicate what they say about the understanding of religion in the field. The analysis will be largely based on the works (i.e. academic journals, monographs and collections) published from 1980 till 2006 - the period when the debate was in its most dynamic phase. Publications emerging after that date seem to rather recycle the existing arguments than add new dimensions to the discussion (e.g. Warner 2010, Turner 2010).

\section{Theoretical issues}

Critics of the secularisation thesis accused it of ideologism and dogmatism. In their view secularisation theories are based on criticisms of religion stemming from the Enlightenment. The authors of those theories were supposed to be not only neutral scholars, but people directly involved in the struggles between new secular and old religious orders (Hadden 1987: 590). As a consequence of this legacy the secularisation thesis was sacrificed, and the process of secularisation began to be treated as evident, even without data supporting its persistence. The secularisation thesis was 'never either rigorously examined or even formulated explicitly and systematically' (Casanova 1994: 17). Answering these accusations, the defenders of the secularisation paradigm stressed that the first secularisation theories were trying to explain the observable processes taking place on both sides of the Atlantic which were researched by the representatives of 'religious sociology' (Hellemans 1998: 68; Berger 2001: 444). Therefore, in their view the secularisation thesis is not an ideology based on anti-religious sentiments, but the first attempt at developing a theory in the field of the sociology of religion, based on empirical data indicating the decline of religious practices and the weakening position of the Christian Churches.

Other areas of fervent discussion concern attempts to define the secularisation process, predictions about the future of religion and the universality of the secularisation model. Striking are the differences in the understanding of the phenomena of religion and secularisation between critics and sup- porters of the secularisation approach. The authors of the rational choice theory of religion - the principal critics of the secularisation thesis - define religion as the individual's choice and experience. Therefore, secularisation is seen as the effect of a change at the individual level and something which concerns individual beliefs, values, affiliations, practices and religious rites (Stark and Bainbridge 1981, Stark 1999). They tend to see secularisation as the disappearance of religion at an individual level and - contrasting this claim with data on beliefs and practices of various religions, including new religions - they show the inadequacy of the thesis. On the other hand, the defenders of the secularisation theory are mostly concerned with the societal location of religion and its power and strength. Consequently, they claim that the main focus of the secularisation process is at societal level (Bruce 2013: 2). It is

a process by which the overarching and transcendent religious system of old is being reduced in a modern functionally differentiated society to a subsystem alongside other subsystems, losing in this process its overarching claims over the other subsystems. As a result, the societal significance of religion is greatly diminished (Dobbelaere 1999: 232).

So it is a social process with social differentiation at its heart. Despite the various stances on the conditions and consequences of that differentiation among different scholars, they stress that changes at the individual level are only one possible consequence of the secularisation process (Wilson 1981, Dobbelaere 1981, Chaves 1994) and that the data on individual religiosity cannot be treated as its only credible and apt measure. Philip Gorski argues that the identification of secularisation with its individual dimension means passing over its core assumptions and focusing on the peripheries of the secularisation thesis (Gorski 2000: 142). Therefore, by focusing on changes at the individual level critics ignore transformations at the societal level, in particular changes in the relations between religion and other social institutions (Chaves 1994: 759).

Discussions also focus on the question of the future of religion in modern and postmodern societies. 
Opponents of secularisation theories claim that these theories see the future of religion as a linear process which involves an unavoidable disappearance of various aspects of religion (Warner 1993). The secularisation process is 'an irreversible trend that will, sooner or later, spell the end of religion and of religious organisations as a significant factor in advanced societies' (Stark and Bainbridge 1981: 161). Alternatively, they propose redefinition of the relationship between religion and modernity and argue for seeing current developments as either a transformation of religion or a cyclical decline and resurgence of religion. The latter argument suggests that secularisation is a self-limiting process, initiating religious resurgence (Stark and Bainbridge 1981: 362). The former standpoint claims that modernisation transforms religion, initiating the emergence of new religions or a transformation of those that already exist (Crippen 1988: 332).

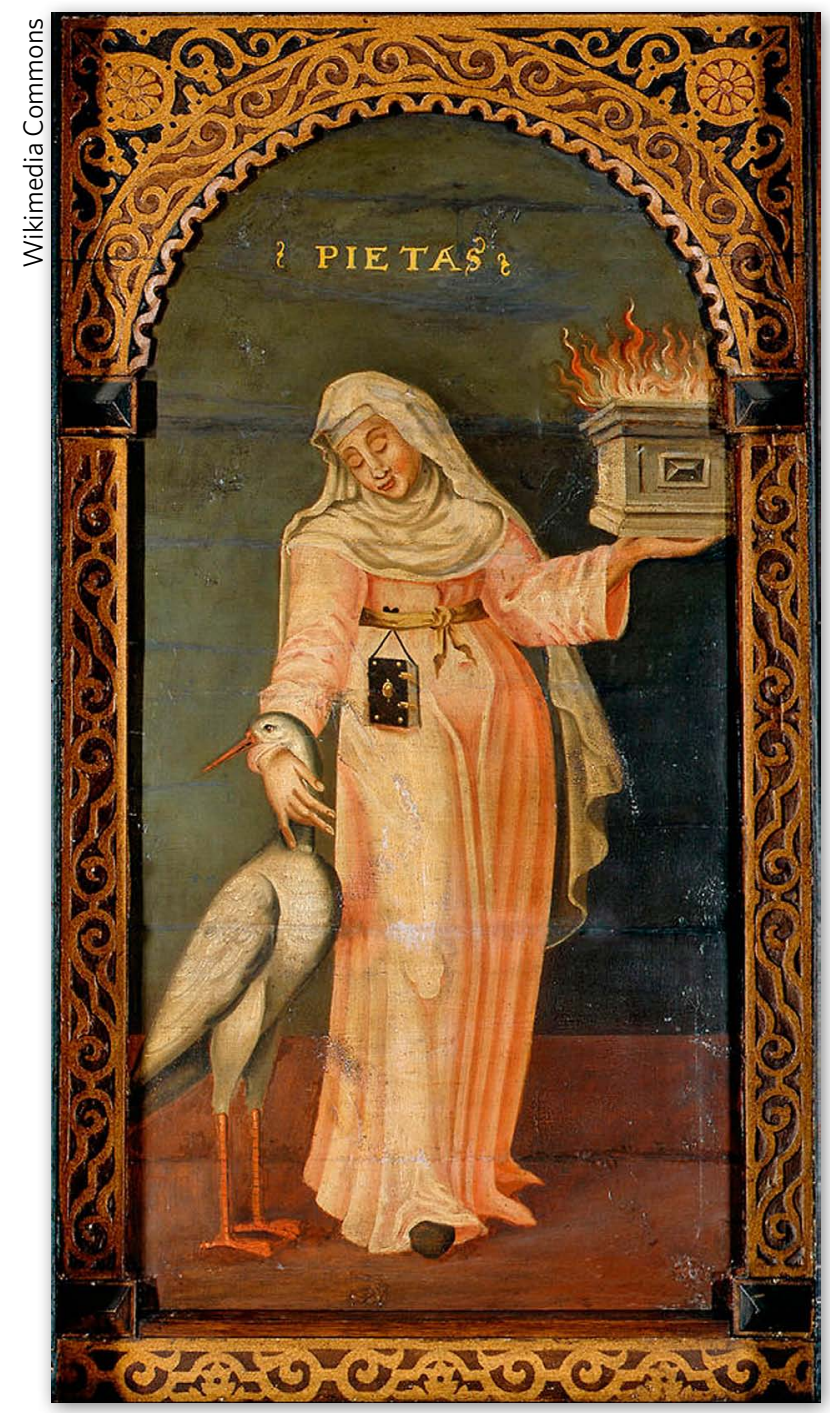

Piety. British School, before 1626.
Answering both these claims, supporters of the secularisation thesis stress that in most secularisation theories the process in question is not presented as linear. Its patterns should be rather described as cyclical/spiral, dialectical, and paradoxical and ones which assume simultaneous occurrences of secularisation and sacralisation (Goldstein 2009: 158). The secularisation process is 'not universal, but context dependent and therefore often non-linear' (Pickel 2011: 4). Moreover, the critics do not seem sufficiently to take into account the societal dimension and the role of new religions in social life (Lechner 1991: 1112). Even if new gods emerge, they will not have an analogous influence on social life as that of the old gods.

The analysis of the arguments of both sides allows for interesting observations regarding the understanding of religion. The defenders of secularisation theory seem in their claims to equate religion with its Christian forms. This is suggested by both the genealogy of secularisation theory (i.e. the European experience of Christianity) and by stressing the societal dimension of religion (i.e. the experience of the dominant Churches in the European context). The cases used by the critics imply broader understandings of religion including both old Christian Churches and denominations and new, individualised forms. Religion is changing its form and functions.

\section{Empirical data as a challenge to the secularisation thesis's claims}

The debate on secularisation became particularly fierce when more and more data and observations started to contradict the predictions of the secularisation thesis. Analysis of the arguments used by both sides allows us to uncover the normative assumptions regarding religion on both sides of the discussion.

\section{Age of piety?}

The 'age of piety' is perceived as a period of time in European history when Christianity maintained a strong position, and is often used by secularisation theories as a contrast to modern times. In other words, it is often presented as a starting point for the process of secularisation. Critics of the secularisation thesis point to new historical research and stress that there was no period of time when religion dominated and the majority of the population was religious or practising (Brown 1992: 38; Swatos and Christiano 1999: 220). As Stark comments: 
Everyone "knows" that once upon a time the World was pious - that in olden days most people exhibited levels of religious practice and concern that today linger only in isolated social subcultures such as the Amish, ultra-orthodox Jews, or Muslim fundamentalists. But, like so many once-upon-a-time tales, this conception of a pious past is mere nostalgia; most prominent historians of medieval religion now agree that there never was an "Age of Faith" (Stark 1999: 255).

Speaking of the decline of religion is therefore unjustified, as there was no time when religion was faring better than it is now.

The defenders of the secularisation thesis answer by stressing that the age of piety means that there were times when the social life and culture of a society were dominated and characterised by religion, and the entire life of a person was controlled by religious institutions (Bruce 2013: 5). They stress that the process of secularisation does not mean the decline of religious practices or of religious institutions' influence on individual lives, but the disappearance of the social functions of religion (Wilson 1981: 207-8; Bruce 2002: 58).

Early modernisation - religious decline or revival?

Critics of the secularisation thesis also refer to data presenting religion in early modern societies (the end of the eighteenth and beginning of the nineteenth century) which, in their opinion, contradict the claim about the decline of religiosity and weakening of religious institutions. The data, mostly from the USA, showing high levels of affiliation to religious institutions, mostly Christian, in early modern times, is used to prove the argument. It shows that migration from villages to cities and urbanisation did not result in a decline in membership of various Churches, which on the contrary managed to successfully mobilise their members, even in industrialised areas (Finke 1992: 156; Finke and Stark 1988: 43).

Hugh McLeod's (1992) views can be presented as a counter-argument to such claims. In his opinion from the end of eighteenth century we can observe periods of both religious decline and resurgence. In the second half of the nineteenth century the decline of religion was caused by various factors: class conflict between the working, middle and upper classes; the development of science; the growing affluence of society and the rise of leisure activities. However, each of these factors could also initiate the resurgence and rise of religious organisations. Those processes spread unevenly in society - they had a different impact, time and speed in its various strata and locations and therefore the author calls for a more nuanced approach.

\section{Pluralism - religious mobilisation or degradation?}

The interpretation of religious pluralism as the fate of religion in the modern world is one of the central elements of the debates on secularisation. Secularisation theories interpret religious pluralism as a threat to the credibility of a religion (Berger 1967, Wilson 1966). Critics of secularisation offer contrasting interpretations. In their opinion religious pluralism is a consequence of deregulation, initiating the free religious market (Finke and Stark 1988: 42; Stark 1992: 262; Stark et al. 1995: 433; Greeley and Hout 1999: 814). Churches, lacking the support and protection of the state, depend only on the number and involvement of their believers; hence they need to make an attractive and appealing offer to their adherents (Finke and Stark 1988: 42; Finke 1990). In this view religious pluralism causes religious resurgence rather than decline. To support such claims Stark and his colleagues use a wide set of data on religious affiliation, religious practices and beliefs from different parts of the world and different historical periods (Iannacone 1991: 156-77; Stark et al. 1995: 191).

Answering these claims, defenders of secularisation theories stress that a distinction needs to be made between the presence of religions in someone's surroundings and the real availability of options. Additionally, deregulation of the religious market - a necessary condition for religious pluralism - may be relative. In various regions of the USA one religious organisation functions informally as a dominant monopoly and plays a crucial role in the social and political life of a given community (Bruce 1992: 191). Some scholars also challenge the research done by Stark and his colleagues. David Voas and his team draw attention to the incorrect interpretation of the results of the research. In their opinion a positive or negative correlation does not reflect dependences, but is rather an artefact being a consequence of a wrong construction of indicators. Moreover, these correlations differ depending on the measures of religiosity (e.g. church affiliation, church attendance). They conclude by saying that it may be the case that religious pluralism does not have any impact on religion (Voas et al. 2002: 213-19).

Other authors stress the contextual character of the relationship between pluralism and secu- 


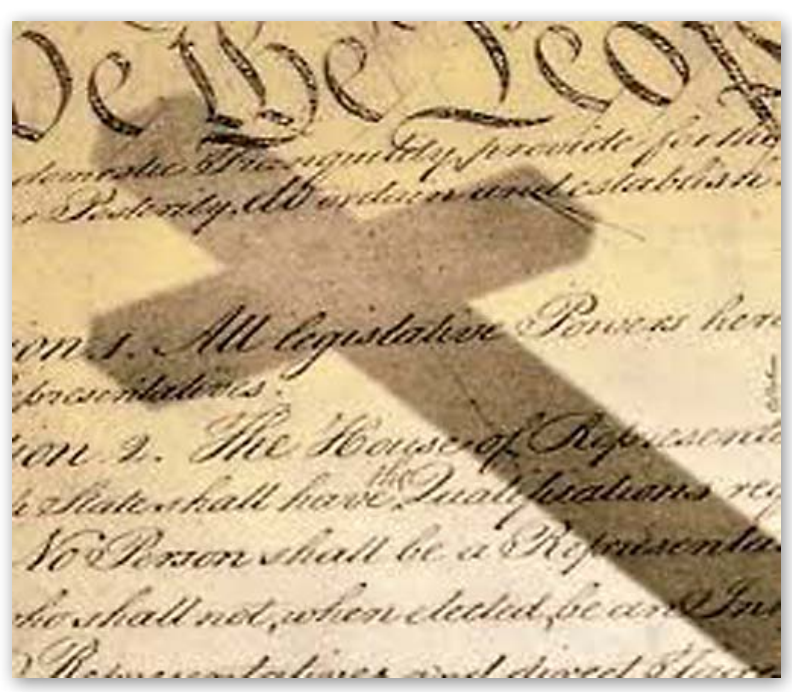

larisation. Peter L. Berger aptly comments on this: '[m] odernity pluralises the lifeworlds of individuals and consequently undermines all taken-for-granted certainties. This pluralisation may or may not be secularising, depending on other factors in a given situation' (Berger 2001: 449).

\section{USA - exception or rule?}

Religious developments in the United States have always posed a challenge to the secularisation thesis and often been referred to as an example in refutations of its claims (i.e. in terms of its high levels of church attendance, of church affiliation and of beliefs in religious dogmas) (Sherkat and Ellison 1999, Greeley and Hout 1999). In response to this, defenders of the secularisation thesis point to some problems with the way the data has been gathered and show that using indirect indicators presents a different picture of the religious involvement of Americans (Hadaway et al. 1993). For example, using such indirect ways of measuring religious involvement indicated a decline in church attendance (Chaves and Stephens 2003: 92). Also, the acceptance of the dogmas central to the Christian belief system seemed to show a tendency to decline and their influence on individuals' activities was rather weak (Gorski 2000: 142; Chaves 1994: 769). There is a consensus on both sides that the USA is, among the most affluent countries, still one of the most religious (Norris and Inglehart 2004: 94). However, the inconsistency of data does not allow for unambiguous interpretation, so we need to be careful not to offer oversimplified stories about the secularisation process or to make excessively hasty repudiations (Chaves and Stephens 2003: 93).
The European religious scene - secularisation or sacralisation? Theories of secularisation were also challenged by the data coming from Western Europe showing that traditional Churches persistently play an important role in politics and policy-making (e.g. the influence of the dominant Churches on family or abortion policy) (Minkenberg 2002), as well as in civil society (e.g. they may define what religion is and through this exclude potential competitors) (Knoblauch 2003: 270). Research also seems to indicate their influential role in shaping the culture of European societies (Casanova 2004; Hervieu-Léger 2001: 125).

Arguments against the secularisation thesis are also based on the discrepancy between various indicators measuring individual religiosity; for example the drop in religious affiliation on the one hand and persistently high levels of belief in God on the other. Critics also point to the process of religious individualisation referring to the data showing such phenomena as 'religion à la carte', 'religious bricolage' or 'believing without belonging.

Refuting arguments regarding the discrepancy of the data on religiosity, Pippa Norris and Ronald Inglehart stress that the secularisation process can neither be confirmed nor rejected by using the data gathered over such a short period of time. Their own research, collecting and comparing data on religious affiliation, church attendance and beliefs in religious dogmas gathered in various research projects from 1947 till 2001, shows a different picture of the dynamics of the European religious scene. In most countries data on religious involvement shows a decline, despite periodical fluctuations. The authors conclude that ' $(t)$ rends in recent decades illustrate the consistency of the secularisation process irrespective of the particular indicator or survey that is selected' (Norris and Inglehart 2004: 87).

However, most often the defenders of the secularisation thesis stress the multidimensionality of the process and lack of a casual relationship between its various levels (Dobbelaere 1999: 245). Furthermore, they argue that this approach mainly applies to the societal level, so the decline or temporary growth of religious practices does not necessary mean the absence of a secularisation process (Wilson 1998: 49).

In the argument reviewed above, both sides of the debate mostly use data on Christian Churches or denominations (in the case of the USA). The main indicators concern churchgoing, church membership and to a lesser extent individual religiosity (i.e. belief in God) - the elements constitutive of the Christian tradition. So the term 'religion', used in general terms, 
in fact reflects Christianity's features and functions. This claim is further supported by the fact that all the arguments are quite ethnocentric - they are geographically limited to the Euro-American context.

\section{Contextualising secularisation}

Critics of the secularisation thesis also use data from the global religious scene showing that the developments taking place outside Europe do not confirm the predictions of secularisation theories; in particular claims that wherever modernisation happens it is accompanied by secularisation. Berger's comment aptly redefines the relations between the two:

... the world, with some notable exceptions..., is as religious as it has ever been, and in some places is more religious than ever. This, however, does not mean that there is no such thing as secularisation; it only means that this phenomenon is by no means the direct and inevitable result of modernity (Berger 2001: 445).

The observations coming from the Middle East, with the Islamic Revolution in Iran presented as a primary example, were most often used to challenge the link between modernisation and secularisation (Hadden 1987: 606; Berger 1999: 7-8). In various countries of that region, secularisation did not emerge along with modernisation. On the contrary, modernisation initiated the revitalisation of Islam, often in its most puritan and fundamental versions (Gellner 1992: 22).

Another example often used to contradict assumptions regarding the link between modernity and secularisation is the success of conservative Protestantism, particularly in the post-colonial countries of Latin America, Sub-Saharan Africa, the Philippines and Southern Asia (China and South Korea in particular). Research also shows such success in Western European countries (Great Britain, the Netherlands and USA) as well as some of the postcommunist countries (e.g. Romania). Conversion to Protestantism, as was documented in the context of Latin America, often means that religion becomes a central value shaping the life of individuals, but also the success of those churches initiated a cultural transformation changing attitudes towards work and consumption, as well as creating a new ethos of education and a challenge to the traditional macho model of masculinity (Berger 1999: 9; Martin 1999: 37). Based on these observations from around the globe Grace Davie suggests adoption of the concept of European religious exceptionalism, stressing the peculiarity of the European experience in respect to the relationship between modernisation and secularisation (Davie 2002).

As a result of the growing body of evidence, the European experiences ceased to serve as a paradigm for understanding the relationship between modernisation and secularisation. In the European context the secularising impact of modernisation was strengthened by those elements of European culture which had their own secularising potential. In other cultural contexts the relationship between the two may have a radically different effect. Examples coming from both the Middle East and the USA are the best illustrations of the reverse impact of modernisation on religion (Inglehart and Baker 2000: 49). The concept of multiple modernities (see Eisenstadt 2000) came to be seen as particularly promising in the attempts to grasp the complex relation between religion and various versions of modernity (Davie 2007: 108-109).

\section{Religious innovations}

The final body of evidence which critics refer to is the data on the widespread existence of new religious movements and phenomena connected to spirituality. New religious movements were at the centre of the attention of the authors of religious economy theory. In their opinion the emergence of new religious movements is a natural stage of religious evolution and in fact a consequence of the secularisation process, ' $[w]$ hen secularisation erodes the power of respectable denominations, it leaves the market for general compensators first to the familiar intensity of sects and then to the novel innovations of cults' (Stark and Bainbridge 1996: 279). Proving their point, the authors refer to the data showing a growing number of new religious movements in the regions where traditional religions are weaker. Hence, the emergence of new religious movements is a direct effect of the secularisation process which, by stimulating religious pluralism and religious competition, in fact contributes to the resurgence of religion.

Defenders of the secularisation thesis refuting this argument interpret the presence of new religious movements in a strikingly different way - they stress the limited scope of the phenomenon and the lack of a wider social impact associated with it (Lechner 1991: 111; Chaves 1994: 759). Furthermore, for some scholars new religious movements present strong evidence supporting the secularisation thesis. In this context Karel Dobbelaere speaks of secularisation at a meso level, which could also be called a religious 
change. According to this argument the new religious movements focus on the immanent reality of mundanity so they should be perceived as a religious adaptation to the secularised world (Dobbelaere 1999: 235-6).

Yet another argument against the secularisation thesis focuses on the widespread presence of new religious forms in late modern Western societies, particularly in Europe. There are different labels used for these phenomena - new, post-industrial, alternative types of religion or spirituality (Houtman and Mascini 2002: 455). Focusing on this type of religion allows us to discover a completely different picture of the European religious scene than that described by secularisation theory. In fact, the picture which emerges presents the religious situation in Europe which is much more similar to the religious situation around the globe. These new forms of religion/spirituality are a consequence of modernisation which did not eliminate the questions about the meaning and aim of life, but only altered the subjects providing these answers. As Danièle Hervieu-Léger stresses, ' $[t] o$ the same degree that modernity does not eliminate the question of sense, it quite certainly produces belief, but it produces atomised, shattered belief, reflecting, in its very crumbling, the reality lived by those concerned' (Hervieu-Léger 1998: 75).

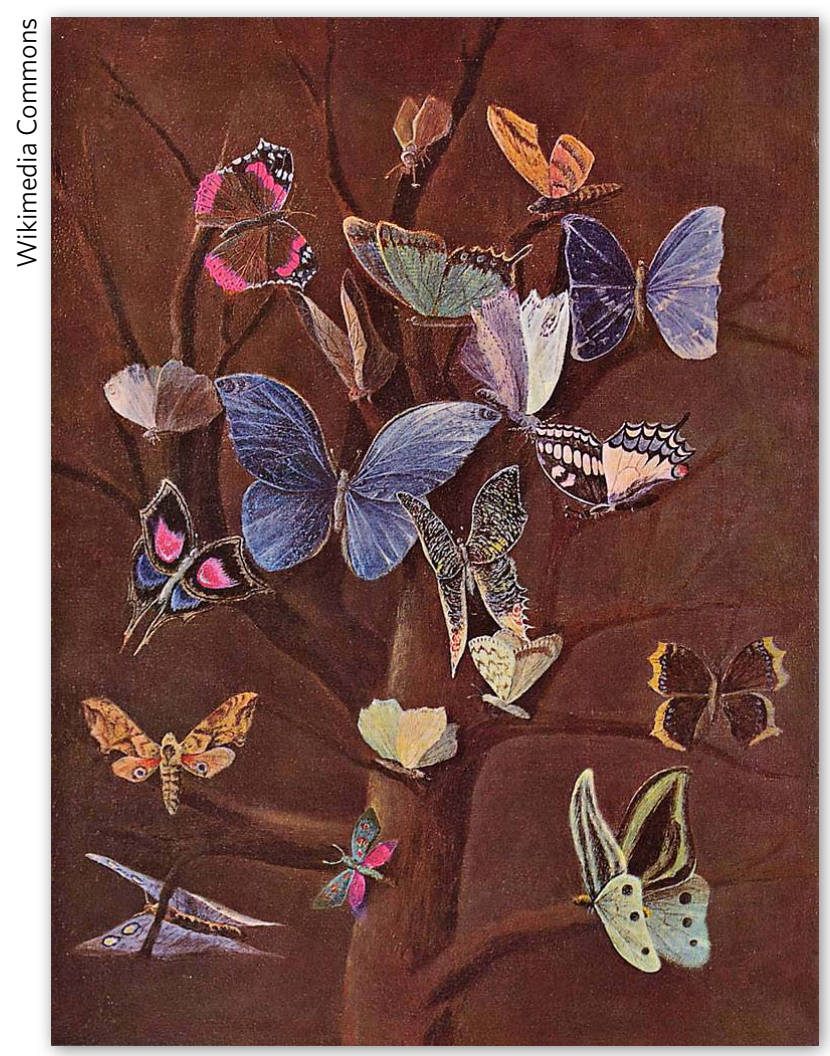

Wilhelm von Kaulbach: Schmetterlinge, c. 1860.
Research in Europe confirms the growing popularity of new religious forms, accompanied by the decline in traditional religiosity. Spirituality as a new form of religion is non-institutional and at best has a form of informal networks. Furthermore, it has a very individualised character - such religions are chosen or constructed by the individual, according to his/her needs and preferences (Knoblauch 2003: 271; Luckmann 2003: 282).

Supporters of the secularisation thesis offer a contrasting interpretation of the existence of invisible religions. In their opinion the presence of such phenomena is proof of the secularisation process. New Age/spirituality is the example par excellence of this latter possibility: a complex of spiritualities which emerges on the foundation of a pluralistic secular society' (Hanegraaff 1999: 151). Additionally, the limited scope of its occurrence as well as the lack of its social influence are considered the main weaknesses in attempts to use the phenomenon of spirituality as an example of a challenge to the secularisation process. Steve Bruce questions the possibility of the phenomenon of spirituality reversing current trends or initiating a wider process of religious revitalisation. In this context it is difficult to speak about refuting the secularisation thesis as for this, in Bruce's opinion, the societal dimension is central (Bruce 2002: 103-5). Resolving the disagreement Paul Heelas points to the subjectivisation thesis as the explanation for both the growth of new religious forms and the decline of the old ones:

As the assumptions, beliefs, and values of the autonomous self oriented toward the subjective life become more widespread in Western cultures, there are progressively fewer traditionalists, conformists, or conservatives who are willing to remain with places of religious worship, let alone to start attending. And autonomous selves are unlikely to participate in forms of worship that require living by an order of things not of their own making, rather than by something from within their own (not dependent) life. (Heelas 2006: 58)

The last arguments indicate the emerging difference in understanding of religion on both sides of the debate. The critics of the secularisation approach refer to the data on non-Western religions (i.e. Islam) and the highly individualised religious forms characteristic of late modern societies. This implies an inclusive understanding of religion, going beyond the Christian 
bias. On the contrary, by stressing the societal location and power of religion, defenders of secularisation seem to still limit the concept of religion to its Christian forms, even if they do not explicitly admit it.

\section{Secularisation - decline of what?}

The debate on secularisation is an interesting case study which reveals certain aspects of the understanding of religion in the contemporary sociology of religion. The presented arguments for and against reveal the normative assumptions (often implicit) lying behind the dispute and allow the understanding of religion to be unpacked in the discussion as a whole. The defenders of the secularisation thesis frequently stress the social importance and centrality of religion in social life in their attempts to refute the arguments of the critics. Taking into account the fact that only traditional religions have the experience of serving as 'sacred canopies' over the whole or part of a society, it seems to suggest that the underlying understanding of religion is limited to such occurrences. The data used to rebut anti-secularisation arguments confirm this - in most cases they are indicators measuring beliefs in Christian dogmas and/or practices in the European context. Such an understanding of religion implies that the new religious movements or 'invisible religions' are by definition excluded as evidences of religious revitalisation. If this is how religion is understood, secularisation is in fact about the loss of the influence and importance of (Christian) religions.

The debate shows that the understanding of religion on the part of the defenders of the secularisation thesis is very ethnocentric - it is very much based on the European experience of Christian Churches in the past holding monopolised and dominant positions in social life. This experience was unjustifiably generalised and universalised. On the contrary, the arguments used by the critics of the secularisation approach show that their understanding of religion is much broader and more inclusive. Not only do they refer to data showing the resurgence of religion in the global world (particularly Islam), reaching beyond the European or Western context, but also to the data on new religious movements and new forms of religion. Clearly, their understanding of religion goes beyond concepts equating religion with its Christian forms. It seems that the criticism of secularisation theory may be interpreted as an attempt to extend the boundaries of the concept of religion, but also more generally as an attempt to 'de-Christianise' and deEuropeanise the sociology of religion.
Katarzyna Zielińska is Lecturer at the Institute of Sociology of the Jagiellonian University. Her academic interests focus on religion in contemporary societies, gender in Central Eastern European societies and transformations of collective identity. She has participated in several research projects such as 'Religion at the European Parlia-

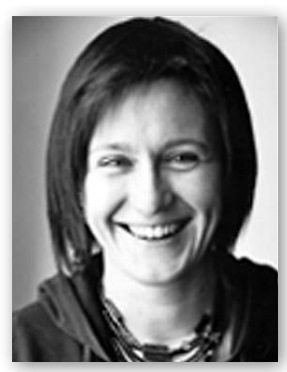
ment' (RelEP) and 'Reconstituting Democracy in Europe' (RECON). Currently she is a leader of the project 'Religion in Polish Politics in the Context of the European Integration'. Her recent publications include: Collective Identity and Democracy in the Enlarging Europe (Peter Lang, 2012, co-edited with M. Góra and Z. Mach); Democracy, State and Society: European Integration in Central and Eastern Europe (Jagiellonian University Press, 2011, co-edited with M. Góra). Email: Katarzyna.zielinska(at)uj.edu.pl

\section{References}

Bellah, Robert 1967. Civil religion in America. Deadalus: Journal of the American Academy of Arts and Sciences 96(1), <http://www.robertbellah.com/articles_5.htm> (accessed on 12.10.2012).

Berger, Peter L. 1967. The Sacred Canopy: Elements of a Sociological Theory of Religion. Garden City: Doubleday, Anchor Books.

-1974. Some second thoughts on substantive versus functional definitions of religion. Journal for the Scientific Study of Religion 13(2) (June): 125-33.

-(ed.) 1999. The Desecularization of the World: Resurgent Religion and World Politics. Michigan: Wm. B. Eerdmans Publishing Company.

-2001 . Reflections on the sociology of religion today. Sociology of Religion 62(4): 443-54.

Brown, Callum G. 1992. A revisionist approach to religious change. In Religion and Modernization: Sociologists and Historians Debate the Secularization Thesis, ed. Steve Bruce, 31-58. Oxford, New York: Oxford University Press.

Bruce, Steve (ed.) 1992. Religion and Modernization: Sociologists and Historians Debate the Secularization Thesis. Oxford, New York: Oxford University Press.

-2002. God Is Dead: Secularization in the West. Oxford: Wiley-Blackwell.

-2011. Defining religion: a practical response. International Review of Sociology 21(1): 107-20.

-2013. Secularisation: in Defence of an Unfashionable Theory. Oxford: Oxford University Press.

Casanova, José 1994. Public Religions in the Modern World. Chicago: University of Chicago Press.

-2004. Religion, European secular identities, and European integration. Eurozine, <http://www.eurozine. com/articles/2004-07-29-casanova-en.html $>$ (accessed on 12.10.2012).

Chaves, Mark 1994. Secularization as declining religious authority. Social Forces 72(3) (March): 749-74. 
Chaves, Mark, and Laura Stephens 2003. Church attendance in the United States. In Handbook of the Sociology of Religion, ed. Michele Dillon, 85-95. Cambridge: Cambridge University Press.

Cohn, Werner, and Samuel Z. Klausner 1962. Is religion universal? Problems of definition. Journal for the Scientific Study of Religion 2(1): 25.

Crippen, Timothy 1988. Old and new gods in the modern world: toward a theory of religious transformation. Social Forces 67(2) (December): 316-36.

Davie, Grace 1998. Invisible religion. In Encyclopedia of Religion and Society, ed. William H. Swatos and Peter Kivisto, 238-9. Walnut Creek, CA: Rowman Altamira.

-2002. Europe: the Exceptional Case. Parameters of Faith in the Modern World. London: Darton, Longman \& Todd Ltd.

-2007. The Sociology of Religion. London: SAGE Publications Ltd.

Dittes, James E. 1969. Secular religion: dilemma of churches and researchers. The H. Paul Douglass lectures of 1968. Review of Religious Research 10(2): 65.

Dobbelaere, Karel 1968. Trend report of the state of the sociology of religion: 1965-1966. Social Compass 15(4) (December): 329-65.

-1981. Trend report. Secularization: a multi-dimensional concept. Current Sociology 29(2) (March): 3-153.

-1999. Towards an integrated perspective of the processes related to the descriptive concept of secularization. Sociology of Religion 6o(3) (September): 229-47.

-2000 . From religious sociology to sociology of religion: towards globalisation? Journal for the Scientific Study of Religion 39(4): 433-47.

-2011. The contextualization of definitions of religion. International Review of Sociology 21(1) (March): 191-204.

-2013. Secularization: in Defence of an Unfashionable Theory. Oxford: Oxford University Press.

Durkheim, Émile 2001. The Elementary Forms of Religious Life. Oxford: Oxford University Press.

Eisenstadt, Shmuel Noah 200o. Multiple modernities. Daedalus 129: 1-29.

Finke, Roger 1990. Religious deregulation: origins and consequences. Journal of Church and State 32(3) (July): 609-26.

-1992. An unsecular America. In Religion and Modernization: Sociologists and Historians Debate the Secularization Thesis, ed. Steve Bruce, 145-69. Oxford, New York: Oxford University Press.

Finke, Roger, and Rodney Stark 1988. Religious economies and sacred canopies: religious mobilization in American cities, 1906. American Sociological Review 53(1) (February): 41-9.

Gellner, Ernest 1992. Postmodernism, Reason and Religion. London: Routledge.

Goldstein, Warren S. 2009. Secularization patterns in the old paradigm. Sociology of Religion 7o(2): 157-78.

Gorski, Philip S. 2000. Historicizing the secularization debate: church, state, and society in late medieval and early modern Europe, ca 1300 to 1700 . American Sociological Review 65(1) (February): 138-67.

Greeley, Andrew M. 1972. Unsecular Man: the Persistence of Religion. New York: Schocken Books.

Greeley, Andrew M., and Michael Hout 1999. Americans' increasing belief in life after death: religious competition and acculturation. American Sociological Review 64(6) (December): 813-35.

Hadaway, C. Kirk, Penny Long Marler, and Mark Chaves 1993. What the polls don't show: a closer look at U.S. church attendance. American Sociological Review 58(6) (December): 741-52.

Hadden, Jeffrey K. 1987. Toward desacralizing secularization theory. Social Forces 65(3) (March): 587-611. doi: $10.2307 / 2578520$.

Hanegraaff, Wouter J. 1999. New Age spiritualities as secular religion: a historian's perspective. Social Compass 46(2) (June): 145-60.

Heelas, Paul 2006. Challenging secularization theory: the growth of "New Age" spiritualities of life. Hedgehog Review 8(1/2): 46-58.

Hellemans, Staf 1998. Secularization in a religiogeneous modernity. In Secularization and Social Integration: Papers in Honor of Karel Dobbelaere, ed. Rudi Laermans, Bryan R. Wilson and Jaak Billiet, 67-79. Leuven: Leuven University Press.

Herberg, Will 1962. Religion in a secularized society: the new shape of religion in America (Lecture I). Review of Religious Research 3(4): 145.

Hervieu-Léger, Danièle 1998. Secularization, tradition and new forms of religiosity: some theoretical proposals. In New Religions and New Religiosity, ed. Eileen Barker and Margit Warburg, 28-44. Aarhus: Aarhus University Press.

-2001. The twofold limit of the notion of secularization. In Peter Berger and the Study of Religion, ed. Linda Woodhead, David Martin and Paul Weithman, 112-25. London: Taylor \& Francis.

Houtman, Dick, and Peter Mascini 2002. Why do churches become empty, while new age grows? Secularization and religious change in the Netherlands. Journal for the Scientific Study of Religion 41(3): 455-73.

Iannacone, Laurence 1991. The consequences of religious market structure: Adam Smith and the economics of religion. Rationality and Society 3(2): 156-77.

Inglehart, Ronald, and Wayne E. Baker 2000. Modernization, cultural change, and the persistence of traditional values. American Sociological Review 65(1) (February): 19-51.

Knoblauch, Hubert 2003. Europe and invisible religion. Social Compass 50(3) (September): 267-74.

Lechner, Frank J. 1991. The case against secularization: a rebuttal. Social Forces 69(4) (June): 1103-19.

Luckmann, Thomas 1963 . On religion in modern society: individual consciousness, world view, institution. Journal for the Scientific Study of Religion 2(2): 147-62. 
-1967. The Invisible Religion: the Problem of Religion in Modern Society. London: MacMillan Publishing Company.

-1977. Theories of religion and social change. The Annual Review of the Social Studies of Religion 1: 1-28.

-2003. Transformations of religion and morality in modern Europe. Social Compass 50(3) (September): 275-85.

Martin, David 1965. Toward eliminating the concept of secularisation. In Penguin Survey of the Social Sciences, ed. Julius Gould, 169-82. Baltimore: Penguin Books.

-1999. The Evangelical Protestant upsurge and its political implication. In The Desecularization of the World: Resurgent Religion and World Politics, ed. Peter L. Berger, 37-50. Michigan: Wm. B. Eerdmans Publishing Company.

Marx, Karl, and Friedrich Engels 2008. On Religion. Mineola, New York: Dover Publications.

McLeod, Hugh 1992. Secular cities? Berlin, London, and New York in the later nineteenth and early twentieth centuries. In Religion and Modernization: Sociologists and Historians Debate the Secularization Thesis, ed. Steve Bruce, 59-89. Oxford, New York: Oxford University Press.

Minkenberg, Michael 2002. Religion and public policy. Comparative Political Studies 35(2) (March): 221-47.

Norris, Pippa, and Ronald Inglehart 2004. Sacred and Secular: Religion and Politics Worldwide. Cambridge: Cambridge University Press.

Pickel, Gert 2011. Contextual secularization: theoretical thoughts and empirical implications. Religion and Society in Central and Eastern Europe 4(1): 3-20.

Robertson, Roland 1970. The Sociological Interpretation of Religion. Oxford: Blackwell.

Schreuder, O. 1966. Sociologie religieuse et recherche socio-ecclésiastique au cours de la période 19621964. Social Compass 13(3) (September): 205-35.

Sherkat, Darren E., and Christopher G. Ellison 1999. Recent developments and current controversies in the sociology of religion. Annual Review of Sociology 25(1): 363-94.

Shupe, Anson, and Jeffrey K. Hadden 1998. Is there such a thing as global fundamentalism? In Secularization and Fundamentalism Reconsidered: Religion and the Political Order, ed. Anson Shupe and Jeffrey K. Hadden, 109-22. New York: Paragon House.

Stark, Rodney 1992. Do Catholic societies really exist? Rationality and Society 4(3) (July): 261-71.

-1999. Secularization, R.I.P. Sociology of Religion 60(3): 249-73.

Stark, Rodney, and William Sims Bainbridge 1980. Towards a theory of religion: religious commitment. Journal for the Scientific Study of Religion 19(2): 114

-1981 . Secularization and cult formation in the Jazz age. Journal for the Scientific Study of Religion 20(4): 360-73.

-1996. A Theory of Religion, reprint. New Brunswick: Rutgers University Press.
Stark, Rodney, R. Finke, and R. Lawrence 1995. Pluralism and piety: England and Wales, 1851. Journal for the Scientific Study of Religion 36: 431-44.

Swatos, William H., and Kevin J. Christiano 1999. Secularization theory: the course of a concept. Sociology of Religion 60(3): 209-28.

Turner, Bryan S. (eds) 2010. Secularization. 4 vols. London: SAGE Publications Ltd.

Voas, David, Alasdair Crockett, and Daniel V. A. Olson 2002. Religious pluralism and participation: why previous research is wrong. American Sociological Review 67(2): 212-30.

Voyé, Liliane 2004. A survey of advance in the sociology of religion (1980-2000). In New Approaches to the Study of Religion: Textual, Comparative, Sociological, and Cognitive Approaches, ed. Peter Antes, Armin W. Geertz and Randi R. Warne, 195-228. Berlin: Walter de Gruyter.

Warner, Rob 2010. Secularization and Its Discontents. London and New York: Continuum International Publishing Group.

Warner, R. Stephen 1993. Work in progress toward a new paradigm for the sociological study of religion in the United States. American Journal of Sociology 98(5) (March): 1044-93.

Weber, Max 1978. Economy and Society. Berkeley and Los Angeles: University of California Press.

Weigert, Andrew J. 1974. Functional, substantive, or political? A comment on Berger's 'Second Thoughts on Defining Religion'. Journal for the Scientific Study of Religion 13(4) (December): 483-6.

Wilson, Bryan 1966. Religion in Secular Society: a Sociological Comment. London: Watts.

-1981. Religion in Sociological Perspective. Oxford, New York: Oxford University Press.

-1998. The secularization thesis: criticisms and rebuttals. In Secularization and Social Integration: Papers in Honor of Karel Dobbelaere, ed. Rudi Laermans, Bryan Wilson, and Jaak Billiet, 45-65. Leuven: Leuven University Press. 